\title{
Vertical Distribution of Functional Potential and Active Microbial Communities in Meromictic Lake Kivu
}

\author{
Özgul İnceoğlu ${ }^{1}$ • Marc Llirós ${ }^{2,6}$ • Sean A. Crowe ${ }^{3}$ - Tamara García-Armisen ${ }^{1}$ • \\ Cedric Morana $^{4}$ - François Darchambeau ${ }^{5}$ - Alberto V. Borges ${ }^{5}$. Jean-Pierre Descy ${ }^{2}$. \\ Pierre Servais ${ }^{1}$
}

Received: 4 December 2014 / Accepted: 2 April 2015

(C) Springer Science+Business Media New York 2015

\begin{abstract}
The microbial community composition in meromictic Lake Kivu, with one of the largest $\mathrm{CH}_{4}$ reservoirs, was studied using 16S rDNA and ribosomal RNA (rRNA) pyrosequencing during the dry and rainy seasons. Highly abundant taxa were shared in a high percentage between bulk (DNA-based) and active (RNA-based) bacterial communities, whereas a high proportion of rare species was detected only in either an active or bulk community, indicating the existence of a potentially active rare biosphere and the possible underestimation of diversity detected when using only one nucleic acid pool. Most taxa identified as generalists were abundant, and those identified as specialists were more likely to be rare in the bulk community. The overall number of environmental parameters that could explain the variation was higher for abundant taxa in comparison to rare taxa. Clustering analysis based
\end{abstract}

Electronic supplementary material The online version of this article (doi:10.1007/s00248-015-0612-9) contains supplementary material, which is available to authorized users.

Özgul İnceoğlu

oezguel@gmail.com

1 Ecologie des Systèmes Aquatiques, Université Libre de Bruxelles, Brussel, Belgium

2 Laboratory of Freshwater Ecology, Université de Namur, Namur, Belgium

3 Departments of Microbiology and Immunology, and Earth, Ocean, and Atmospheric Sciences, University of British Columbia, Vancouver, Canada

4 Department of Earth and Environmental Sciences, Katholieke Universiteit Leuven, Leuven, Belgium

5 Chemical Oceanography Unit, Université de Liège, Liège, Belgium

6 Present address: Department of Genetics and Microbiology, Universitat Autònoma de Barcelona, Bellaterra, Spain on operational taxonomic units (OTUs at 0.03 cutoff) level revealed significant and systematic microbial community composition shifts with depth. In the oxic zone, Actinobacteria were found highly dominant in the bulk community but not in the metabolically active community. In the oxic-anoxic transition zone, highly abundant potentially active Nitrospira and Methylococcales were observed. The cooccurrence of potentially active sulfur-oxidizing and sulfatereducing bacteria in the anoxic zone may suggest the presence of an active yet cryptic sulfur cycle.

Keywords Bacteria $\cdot$ Archaea $\cdot$ Pyrosequencing $\cdot$ Active $\cdot$ Bulk $\cdot$ qPCR $\cdot$ Network $\cdot$ Abundant and rare $\cdot$ Meromictic lake

\section{Introduction}

Meromictic lakes are good model systems for microbial ecology research due to the high vertical stability of the water masses and physicochemical gradients (in particular oxygen) that lead to relatively constant stratification of microbial populations [1-3]. Since microbes are key players in biogeochemical cycles, investigations on microbial diversity and community composition are important to understand the ecological functioning of lakes. Environmental heterogeneity was shown to produce community differences in lakes $[4,5]$. According to Lennon and Jones [6], core community shifts, including active, dormant, and dead cells, may vary widely along vertical gradients, contributing to the community dynamics as well as to the maintenance of ecosystem biodiversity and ecosystem stability. Currently, high-throughput sequencing technology provides an opportunity to detect greater microbial diversity than the one detected by previous techniques [7-9]. It has revealed that the core community is composed of abundant and rare taxa that are in continuous exchange based on the 
environmental gradients [10]. However, most recent studies were based on bulk community composition (i.e., DNA-based 16S ribosomal RNA (rRNA) genes) and did not distinguish between functionally active (i.e., RNA-based 16S rRNA genes) or dormant populations [11]. Even though potential biases can be introduced during DNA and RNA extraction, complementary DNA (cDNA) synthesis, and PCR amplification [12], parallel comparisons of DNA- and RNA-based pyrosequencing approaches can help differentiate whether abundant taxa are active or whether rare but active taxa exist. In addition, stronger evidence on the links between biogeochemical processes and microbial communities might be obtained if active communities are monitored rather than bulk communities [13-16].

Lake Kivu in East Africa is a meromictic lake with a permanent density stratification separating the oxicmixolimnion from a deep anoxic monolimnion rich in dissolved salts, carbon dioxide $\left(\mathrm{CO}_{2}\right)$, and methane $\left(\mathrm{CH}_{4}\right)$ [17]. In spite of the presence of high amounts of $\mathrm{CH}_{4}$ at the bottom of Lake Kivu, the $\mathrm{CH}_{4}$ concentration in the oxic zone is surprisingly low compared to other lakes globally, due to intense microbial methane oxidation $[18,19]$. The vertical stratification of microbial taxa and their potential role in biogeochemical cycles in Lake Kivu were recently studied for both archaeal and bacterial counterparts using DNA-based analysis, and important key players of carbon, nitrogen, and sulfur cycles were identified $[20,21]$. Furthermore, evaluation of the effect of temporal variations on abundant versus rare taxa in different layers revealed that abundant taxa were more stable between two sampling times than rare ones, indicating a potentially higher contribution of rare taxa to biogeochemical processes [20]. Therefore, in the present study, Lake Kivu was investigated as a model ecosystem by comparative DNA- and RNAbased pyrosequencing of bacterial and archaeal communities in two different seasons (i) to check if bulk (DNA) and potentially active (RNA) microbial communities have the same composition through the water column and (ii) to explore if rare bulk and potentially active taxa respond to environmental changes as abundant taxa do in Lake Kivu. Furthermore, the abundance of key genes related to the carbon (particulate methane monooxygenase gene (pmoA) and methyl coenzyme-M reductase gene ( $m c r A)$ ) and nitrogen (ammonia monooxygenase gene (amoA), nitrite reductase gene (nirK) and nitrous oxide reductase (nosZ)) biogeochemical cycles was measured to evaluate the functional potential and their response to environmental changes.

\section{Materials and Methods}

Study Site and Sampling Meromictic and oligotrophic Lake Kivu is located between Rwanda and the Democratic Republic of the Congo at $1463 \mathrm{~m}$ above sea level. It has a surface area of $2370 \mathrm{~km}^{2}$, a total volume of $580 \mathrm{~km}^{3}$, and a maximum depth of $485 \mathrm{~m}$. Surface waters are considered to be oligotrophic with moderate primary production compared to other African lakes $[22,23]$. Further details on the hydrology, physicochemistry, and biology of the lake are published elsewhere [22-25]. In order to study the microbial communities in the water column of Lake Kivu, water samples were collected from the upper $100 \mathrm{~m}$ of the water column in the North basin (off Gisenyi; $29.24^{\circ} \mathrm{E},-1.72^{\circ} \mathrm{N}$ ). Water samples were collected during two sampling campaigns during both rainy (RS, February 2012) and dry seasons (DS, September 2012). Up to 20 discrete depths were sampled along a vertical profile between 1 and $100 \mathrm{~m}$ to cover the whole gradient of oxygen concentrations (from oxic to anoxic waters). Water samples for chemical and microbiological analyses were collected using a 7.5-L Niskin bottle and stored in 4-L plastic containers for chemical analyses (except for $\mathrm{CH}_{4}$ and $\mathrm{HS}^{-}$) and 2-L Nalgene plastic bottles for biological analyses. Water samples for DNA and RNA extractions were immediately passed through 5.0- $\mu \mathrm{m}$ pore size filters (ISOPORE, Millipore, MA) to remove particulate debris as well as large protozoa. Eluents were then passed through $0.22-\mu \mathrm{m}$ pore size filters (ISOPORE, Millipore, MA) to retain free-living prokaryotes. Filters for DNA extraction were preserved in Lysis Buffer as previously described [21], whereas filters for RNA extraction were preserved in $300 \mu \mathrm{L}$ of RNAlater (Ambion) and all stored frozen until further analyses.

Chemical Analyses Temperature, conductivity, $\mathrm{pH}$, and dissolved oxygen (DO) vertical depth profiles were measured in situ with a YSI 6600 V2 (Yellow Spring Instruments, USA) multiparametric probe. According to Wright et al. [26], the upper $100 \mathrm{~m}$ of the water column of Lake Kivu was split into three distinct vertical layers: an oxic surface layer (DO> $90 \mu \mathrm{M}$ ), a transition zone (DO between 1 and $90 \mu \mathrm{M}$ ), and a deep anoxic zone $(\mathrm{DO}<1 \mu \mathrm{M}$; Fig. 1). The concentration of methane $\left(\mathrm{CH}_{4}\right)$ was measured using the headspace technique with a gas chromatograph with a flame ionization detector as previously described [18]. Samples for $\mathrm{NO}_{\mathrm{x}}$ and $\mathrm{SO}_{4}{ }^{2-}$ were filtered directly through $0.2-\mu \mathrm{m}$ pore size cellulose acetate syringe filters. $\mathrm{NH}_{4}{ }^{+}$concentrations were determined using the dichloroisocyanurate-salicylate-nitroprussiate colorimetric method [27]. $\mathrm{NO}_{2}{ }^{-}$concentrations were determined by the sulfanilamide coloration method [28]. $\mathrm{NO}_{3}{ }^{-}$concentrations were determined after vanadium reduction to nitrite and quantified in this form following the nitrite determination procedure $[28,29] . \mathrm{SO}_{4}{ }^{2-}$ concentrations were measured using ion chromatography. Samples for $\mathrm{HS}^{-}$determination were not filtered but preserved instead with zinc acetate and stored frozen. $\mathrm{HS}^{-}$concentrations were measured spectrophotometrically [30]. The detection limits for these methods were $0.5 \mathrm{nM}$ for $\mathrm{CH}_{4}$ and $0.3,0.03,0.1,2$, and $0.5 \mu \mathrm{M}$ for $\mathrm{NH}_{4}{ }^{+}, \mathrm{NO}_{2}{ }^{-}, \mathrm{NO}_{3}{ }^{-}$, $\mathrm{SO}_{4}{ }^{2-}$, and $\mathrm{HS}^{-}$, respectively. Samples for particulate organic carbon concentration (POC) were filtered on precombusted 


\section{February (RS)}

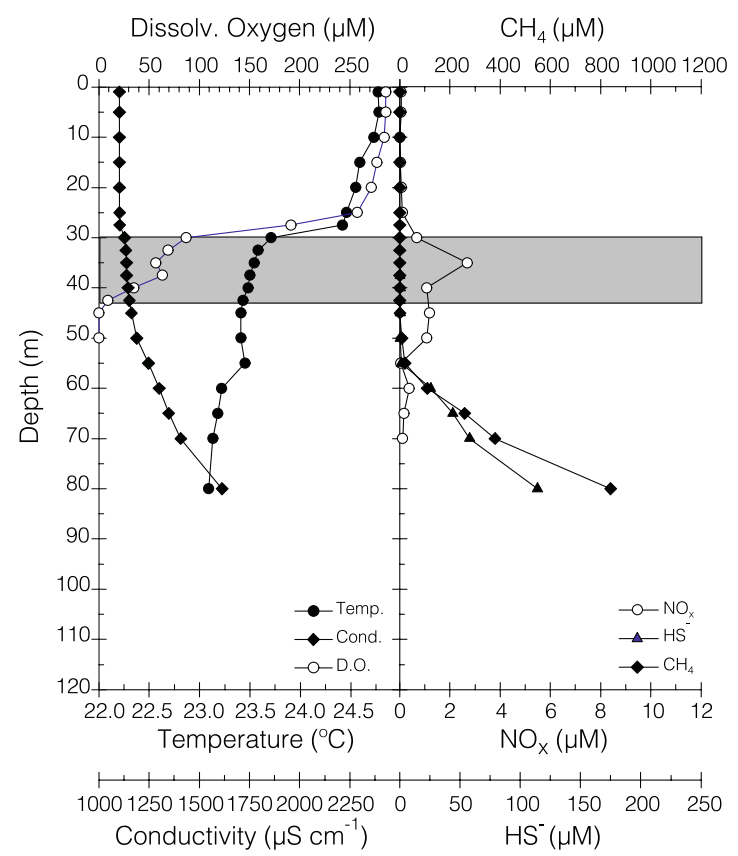

September (DS)

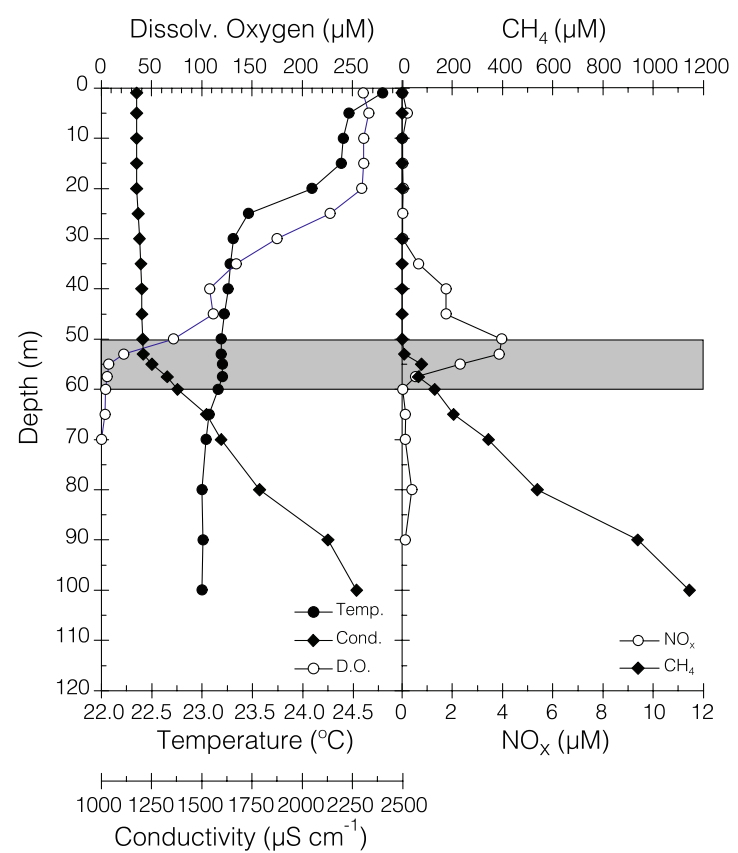

Fig. 1 Depth profiles of temperature, conductivity and dissolved oxygen (DO), nitrite and nitrite $\left(\mathrm{NO}_{\mathrm{x}}\right), \mathrm{CH}_{4}$, and $\mathrm{HS}^{-}$concentrations during the two sampling campaigns (February (RS) and September (DS)). The transition zones were indicated with a gray bar

(overnight at $450^{\circ} \mathrm{C}$ ) 25 -mm glass fiber filters (Advantec GF$75 ; 0.3 \mu \mathrm{m})$ and dried. These filters were later decarbonated with $\mathrm{HCl}$ fumes for $4 \mathrm{~h}$ and then dried and packed in silver cups. POC was determined by elemental analysis-isotope ratio mass spectrometry (EA-IRMS, ThermoFlashHT with Thermo Delta V Advantage). POC was calibrated with International Atomic Energy Agency (IAEA-C6) and acetanilide.

Chlorophyll a (Chla) concentrations were determined using high-performance liquid chromatography (HPLC). At each sampling depth, $3 \mathrm{~L}$ of water were filtered on a Macherey-Nägel GF-5 filter (nominal porosity, $0.4 \mu \mathrm{m}$ ). Pigment extraction was carried out in $10 \mathrm{~mL}$ of $90 \%$ HPLC grade acetone (Fisher Scientific). After two 15-min sonication steps separated by an overnight period at $4{ }^{\circ} \mathrm{C}$, the extracts were stored in $2-\mathrm{mL}$ amber vials at $-25^{\circ} \mathrm{C}$. HPLC analysis was performed following the method described in Sarmento et al. [23]. Commercial external standards (DHI Lab Products) were used for calibration.

Nucleic Acid Extraction DNA was extracted using a combination of enzymatic cell lysis and the cetyltrimethyl ammonium bromide (CTAB) extraction protocol as previously described [20,31]. Dry DNA pellets were finally rehydrated in $50 \mu \mathrm{L}$ of $10 \mathrm{mM}$ Tris- $\mathrm{HCl}$ buffer (pH 7.4).

Total RNA was extracted using a mirVana RNA isolation kit (Ambion, Austin, TX, USA; [32]). RNA samples were treated with the Turbo DNA-free kit (Ambion, Austin, TX, USA), and cDNA synthesis was performed with the iScript reverse transcription supermix (Bio-Rad) in a MasterCycler
5331 Gradient (Eppendorf, Hamburg, Germany). Possible DNA contamination of RNA templates was routinely monitored by PCR amplification of RNA aliquots that were not reverse transcribed. No contaminating DNA was detected in any of these reactions.

Real-Time Quantitative PCR qPCR was used to quantify the presence of distinct functional genes. The following genes were used as proxies for quantification of DNA: the bacterial alpha subunit of the particulate methane monooxygenase enzyme ( $p m o A$ ) for methanotrophs, the archaeal alpha subunit of methyl-coenzyme $\mathrm{M}$ reductase enzyme gene $(\mathrm{mcr} A)$ for methanogens, the alpha subunit of the archaeal ammonia monooxygenase enzyme gene ( $a m o A$ ) for archaeal ammonia oxidation, the bacterial copper-containing nitrite reductase gene (nirK), and the cytochrome cd1-containing nitrite reductase gene (nosZ) for bacterial denitrification. All qPCR assays were performed in a StepOne Real-Time PCR system (Applied Biosystems, Foster City, CA, USA) using the primers and thermal conditions described in Table 1. All reactions were performed in triplicate for both serial dilutions of titrated standards and unknown templates using a $20 \mu \mathrm{L}$ reaction mixture consisting of the $1 \times$ PowerSYBR green PCR master mix (Applied Biosystems), each primer (Table 1), and DNA templates of known concentrations of standards or $20 \mathrm{ng}$ DNA extracted from water samples. The specificity of the amplification products was further confirmed by melting curve analyses, and the expected sizes of the amplified fragments were checked on a $1 \%$ agarose gel. Overall, average efficiencies for 


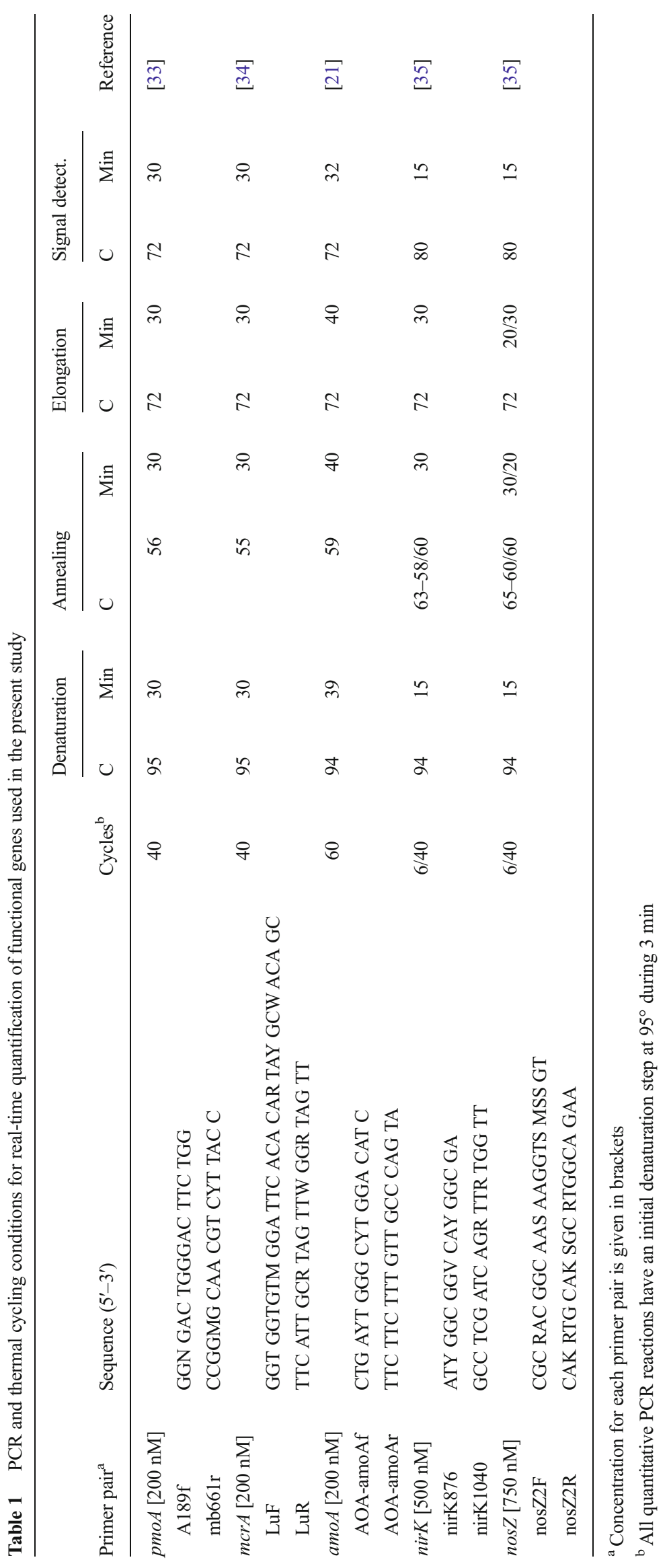


all quantification reactions ranged from 0.88 to 0.97 with $R^{2}$ values $>0.99$. Standard curves were generated from serial dilutions of previously titrated suspensions of the desired genes from isolates or environmental clones, purified (QIAquick; Qiagen), and quantified. Statistical analyses (ANOVA and Tukey's HSD) were performed to compare differences between water zones (oxic, transition, anoxic) [36].

\section{S Tag-Encoded FLX-Titanium Amplicon} Pyrosequencing Bacterial and archaeal tag-encoded FLX amplicon pyrosequencing (bTEFAP and aTEFAP, respectively), analyses by means of a Roche 454 FLX instrument with titanium reagents, were performed at the Research and Testing Laboratory (Lubbock, TX, USA) as described previously [37, 38]. The PCR primers for FLX amplicon pyrosequencing were chosen to span the variable V1-V3 regions in the 16S rRNA gene: 27 F (5'-GAGTTTGATCNTGGCTCAG-3') and 519R (5'-GWNTTACNGCGGCKGCTG-3') for bacteria and V3V4 regions ARCH 349 F (5'-GYGCASCAGKCGMGAAW3') and ARCH 806R (5'-GGACTACVSGGGTATCTAAT-3') for archaea. These primers cover about 78 and $70 \%$ of publicly available 16S rRNA for bacteria and archaea, respectively (check using TestPrime tool available at SILVA webpage (http://www.arb-silva.de/search/testprime/)).

Pyrosequencing Data Analyses All sequences generated in this study can be downloaded from the National Center for Biotechnology Information (NCBI) Short Read Archive, accession number: SRP021176. Pyrosequencing data were processed using Mothur [40]. To minimize the effects of random sequencing errors, a denoising algorithm (shhh.flows) included in the pipeline is used and low-quality sequences were removed by eliminating those without an exact match to the forward primer, without a recognizable reverse primer, with a length shorter than 200 nucleotides, and those containing any ambiguous base calls. We trimmed the barcodes and primers from the resulting sequences. Chimeric sequences were removed using the Uchime software [39] implemented in Mothur [40]. The latest Greengenes and SILVA databases were used for classification of bacterial and archaeal 16S rRNA gene sequences, respectively, at a $80 \%$ confidence threshold using Mothur. After taxonomic assignment of the sequences to the phylum, class, and genus level, relative abundance of a given phylogenetic group was set as the number of sequences affiliated with that group divided by the total number of sequences per sample. The sequences retrieved were grouped based on oxygen stratification as oxic, transition, and anoxic zones.

Sequences were clustered into operational taxonomic units (OTUs) by setting a 0.03 distance limit (equivalent to $97 \%$ similarity). A data matrix was created based on the relative abundance of genus and OTU. The relative abundances were square root transformed. Dendrograms were generated based on the Bray-Curtis similarity index using complete linkage clustering. Furthermore, the scatterplot depicted the relationship between the depths and observed species-based BrayCurtis similarity. The discrimination of microbial assemblages based on time and stratification was tested with one-way analysis of similarities (ANOSIM). Unless otherwise stated, all the analyses were performed using PRIMER 6 [41].

To measure habitat specialization, the niche breadth approach was used, as described previously $[42,43]$. The niche breadth $\left(B_{\mathrm{j}}\right)$ was calculated using the following equation:

$$
B_{j}=\frac{1}{\sum_{i=1}^{N} P_{i j}^{2}}
$$

in which $P_{\mathrm{ij}}$ is the proportion of individuals belonging to species $j$ present in a given habitat $i$. OTUs with a high $B_{\mathrm{j}}$ value indicate a wide range of habitats, which can be considered as habitat generalists. Similarly, OTUs with a low value can be assigned as habitat specialists.

Furthermore, the data sets were split into two groups: Taxa represented by more than 15 sequences per sample were defined as abundant taxa, and taxa that had fewer than 15 sequences were considered rare. Venn diagrams of OTUs were constructed to illustrate the number of shared OTUs (both subsampled and not subsampled) for the two sampling campaigns based on DNA and RNA. A relative abundance matrix for OTUs was created for sampling times and points pooled, and those OTUs that appeared less than five times were removed from the matrix. For network inference, Pearson's rank correlations were calculated between OTUs with CoNet [44], when coefficient $(r)$ was both above 0.8 and statistically significant (adjusted $p$ value $<0.01$ with Benjamini-Hochberg). The data matrix was translated into an association network using Cytoscape 2.6.3 [44, 45]. Cytoscape depicts data sets as nodes (tribes) connected by lines that denote the positive correlation. In the network, the size of each node is proportional to the number of connections (degree) and the node border color indicates if the OTU is either abundant or rare.

We further quantified the influences of environmental variables $\left(\mathrm{pH}+\mathrm{DO}+\mathrm{NO}_{\mathrm{x}}+\mathrm{POC}+\mathrm{CH}_{4}+\mathrm{Chl}-a\right)$, depth, and season on bacterial community variation using variation partitioning analyses [46], with the varpart function of the vegan package $[47,36]$. If any colinearity was present, it would be revealed by the analysis.

\section{Results}

\section{Environmental Parameters}

Lake Kivu is characterized by vertical gradients in temperature, $\mathrm{pH}$, conductivity, $\mathrm{DO}, \mathrm{CH}_{4}$, and $\mathrm{HS}^{-}$(Fig. 1). Surface waters were characterized by high $\mathrm{DO}$ content and low $\mathrm{NO}_{\mathrm{X}}$ 
and $\mathrm{CH}_{4}$ concentrations, whereas the anoxic deep waters were characterized by high concentrations of $\mathrm{NH}_{4}^{+}$and dissolved $\mathrm{CO}_{2}$ and $\mathrm{CH}_{4}$ [18]. $\mathrm{NO}_{\mathrm{x}}{ }^{-}$showed maximum values in the oxic-anoxic transition zone, whereas increasing concentrations with depth of $\mathrm{HS}^{-}(>50 \mu \mathrm{M})$ and $\mathrm{CH}_{4}(>100 \mu \mathrm{M})$ were only observed in the anoxic zone (Fig. 1). The mixed oxic zone was deeper during the DS than during the RS with a more gradual decrease in DO with depth and a steady increase in $\mathrm{NO}_{\mathrm{x}}$ values toward the chemocline (Fig. 1). The $\mathrm{pH}$ decreased with depth over the first 100-m depth (data not shown). POC concentration was higher in the oxic water than in the anoxic zones during both sampling campaigns and was slightly higher in the oxic water compartments in DS than in RS (data not shown).

qPCR In the current study, functional genes involved in key processes of carbon and nitrogen cycles were measured by genomic DNA qPCR. In relation to the carbon cycle, the pmo $A$ gene was used to quantify the bacterial methanotrophs and the $m c r A$ gene to quantify archaeal methanogens and methanotrophs. Concerning the $\mathrm{N}$ cycle, the amoA gene was used to quantify archaeal ammonia oxidizers (AOA) while the nirK and nos $Z$ genes were used to quantify bacterial denitrifiers.

In RS, pmo $A$ gene copies ranged between $1.13 \times 10^{3}$ and $2.92 \times 10^{4}$ gene copies $\mathrm{mL}^{-1}$, whereas in DS, the values varied between $4.19 \times 10^{2}$ and $9.63 \times 10^{4}$ gene copies $\mathrm{mL}^{-1}$ throughthe water column. In DS, more $p m o A$ gene copies were measured in the transition zone ( $p<0.05$, Fig. 2$)$ than in RS. Concerning archaeal methanogens and methanotrophs, $m c r A$ gene copies were only detected in the anoxic zone with abundance ranging between $8.00 \times 10^{2}$ and $3.53 \times 10^{3}$ gene copies $\mathrm{mL}^{-1}$ in RS (Fig. 2), whereas lower values were recovered in DS $\left(4.15 \times 10^{2}\right.$ to $2.21 \times 10^{3}$ gene copies $\left.\mathrm{mL}^{-1}\right)$. The difference between sampling dates was not statistically significant.

The numbers of archaeal amo $A$ gene copies were used to investigate the vertical distribution and abundance of AOA in relation to the $\mathrm{NO}_{\mathrm{x}}$ profile available for both sampling campaigns. The quantitative distribution varied with depth, and

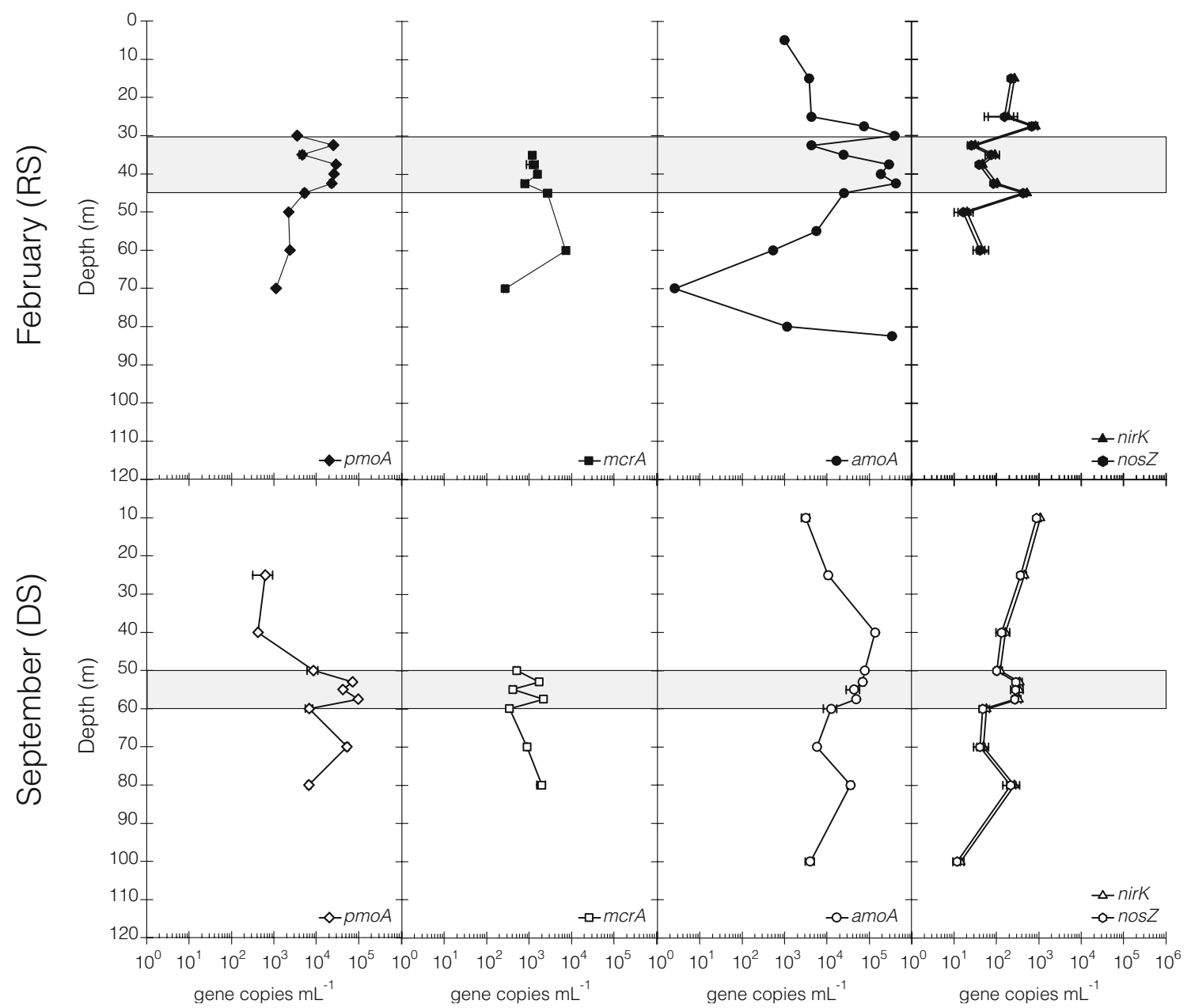

Fig. 2 Depth profiles of gene copy numbers for $p m o A, m c r A$, amoA, and nirK/nos $Z$ genes determined by quantitative PCR for two sampling campaigns (February (RS) and September (DS)). Error bars represent

the standard deviation from triplicates. The transition zones were indicated with a gray bar 
the highest copy numbers were mainly observed in the oxic and transition zones (from 30.0 to $42.5 \mathrm{~m}$ in RS and from 40.0 to $57.5 \mathrm{~m}$ in DS). The maximum values were $4.2 \times 10^{5}$ and $2.5 \times 10^{4}$ gene copies $\mathrm{mL}^{-1}$ in $\mathrm{RS}$ and DS, respectively (Fig. 2). Furthermore, functional genes involved in bacterial denitrification (i.e., nirK and nosZ genes) showed similar depth patterns during both seasons with rather low values (never exceeding $1 \times 10^{3}$ gene copies $\mathrm{mL}^{-1}$; Fig. 2). Oxic waters had significantly higher densities of nirK than in transition zone $(p<0.05)$ and higher densities of nos $Z$ than anoxic water in September $(p<0.05)$. During the RS, no clear pattern with depth was observed, but higher values were observed at 27.5 and $45 \mathrm{~m}$, whereas during the DS, maximum values were observed at $10 \mathrm{~m}$ and decreased regularly with depth, with a slight increase at the oxic-anoxic transition zone.

\section{Pyrosequencing Overview and Community $\beta$-Diversity} After removing the noise and poor-quality reads with Mothur, about 34,097 bacterial DNA reads and 27,095 bacterial RNA reads were used for subsequent analyses. Rarefaction analysis indicated that most of the bacterial libraries may require deeper sequencing to avoid underestimation of microbial diversity in the samples (Table S1). Samples were randomly subsampled to the smallest sampling size using Mothur in order to reduce bias in species richness due to the differences in the number of sequences. The number of bacterial OTUs increased with depth for both DNA and RNA-based bacterial communities (Table S1). Richness estimates of the RNAbased bacterial community in the deepest anoxic waters were slightly higher than the DNA-based community in RS, whereas richness estimates of the DNA-based bacterial community in anoxic waters were higher than the estimates of the potentially active bacterial community in DS. The number of observed bacterial species per depth ranged from 127 to 240 in RS and 237 to 603 in DS for bulk and active bacterial communities, respectively (Table $\mathrm{S} 1$ ). The Chaol estimator predicted richness values in the range of 324-988 in RS and 4922234 in DS. Moreover, rank-abundance curves of DNA- and RNA-based bacterial communities showed a power-law distribution, which had a few abundant OTUs and a long tail of low-abundant species (Fig. S1). Venn diagrams also suggested that highly abundant taxa were common in a high percentage between DNA- and RNA-based communities. In contrast, a high proportion of rare species was determined to be specific to either DNA- and RNA-based community (Fig. 3).

In turn, 16,700 archaeal DNA reads and 2573 archaeal RNA reads were recovered for subsequent analyses. No high-quality sequences were retrieved from $15,25,35$, and 50 m RNA samples in RS and from 10, 25, 40, 50, and $53 \mathrm{~m}$ DNA and RNA samples in DS. Rarefaction analysis based on OTUs indicated that most of the archaeal libraries reached the plateau level with the exception of the $40 \mathrm{~m}$ RNA sample in RS and the $80 \mathrm{~m}$ RNA sample in DS. In general terms, richness was higher in the anoxic zone than in the oxic zone during both sampling times. During both seasons, archaeal richness estimates (i.e., Chaol estimator) predicted lower richness values in the oxic and oxic-anoxic transition zone than in the anoxic waters (Table S2). No clear richness differences were observed between DNA- and RNA-based archaeal communities in oxic and oxic-anoxic transition zones, whereas richness estimates were higher for DNA samples than RNA samples in the anoxic zone (Table S1).

Bacterial Community Composition Analysis Between 7 and $42 \%$ of the bacterial sequences analyzed were unclassified, with an increasing proportion toward the anoxic zone. Altogether, 34 distinct bacterial phyla were recovered from DNA samples and 29 phyla from RNA samples in RS, while 43 phyla were recovered from DNA samples and 29 phyla from RNA samples in DS. Actinobacteria, Proteobacteria (Alphaproteobacteria, Betaproteobacteria, Epsilonproteobacteria, and Gammaproteobacteria), Cyanobacteria, Planctomycetes, Bacteroidetes, Chlorobi, Chloroflexi, and Nitrospirae were detected both in the DNAand RNA-based bacterial communities (Fig. 4, S2A-I). In DNA- and RNA-based communities, candidate bacterial phyla such as GN02, OP3, OP8, NC10, NKB19, TM6, and WS1 were mostly detected in the anoxic zone but never exceeding relative abundance of $1 \%$. The comparison of the DNA- and RNA-based bacterial communities revealed similar relative abundance of the numerically dominant taxa with the exception of a lower relative abundance of Actinobacteria (Fig. 4, S2B) and a higher abundance of Planctomycetes (Fig. 4, S2C) and Bacteroidetes (Fig. 4) in the potentially active bacterial community composition (BCC) with respect to DNA-based bacterial community in the oxic zone. The $\mathrm{BCC}$ is further described in the co-occurrence patterns of the bacterial taxa section.

Bray-Curtis similarity trees were constructed based on total OTU composition of the 47 bacterial RNA and DNA samples to determine the associations among the communities. Clustering and ANOSIM analyses revealed the stratification (three zones based on DO concentrations) as the most important factor in structuring both DNA- and RNA-based BCC (Fig. 5). Although the clustering showed the grouping of the samples by DO zones, no similarity higher than $60 \%$ was observed between samples. When the DNA- and RNAbased bacterial communities were compared based on BrayCurtis distances against depth, significant negative correlations were observed (Fig. 6), with higher slopes (m) and linear correlation coefficients (R) for DNA- than RNA-based BCC ( $m=-6.48, R=0.77$ for the bulk community and $m=-3.58$, $R=0.47$ for the potentially active community), suggesting more rapid changes in the DNA-based BCC with depth than in the RNA-based community. Moreover, the BCC differed significantly and systematically depending on whether DNA 
A
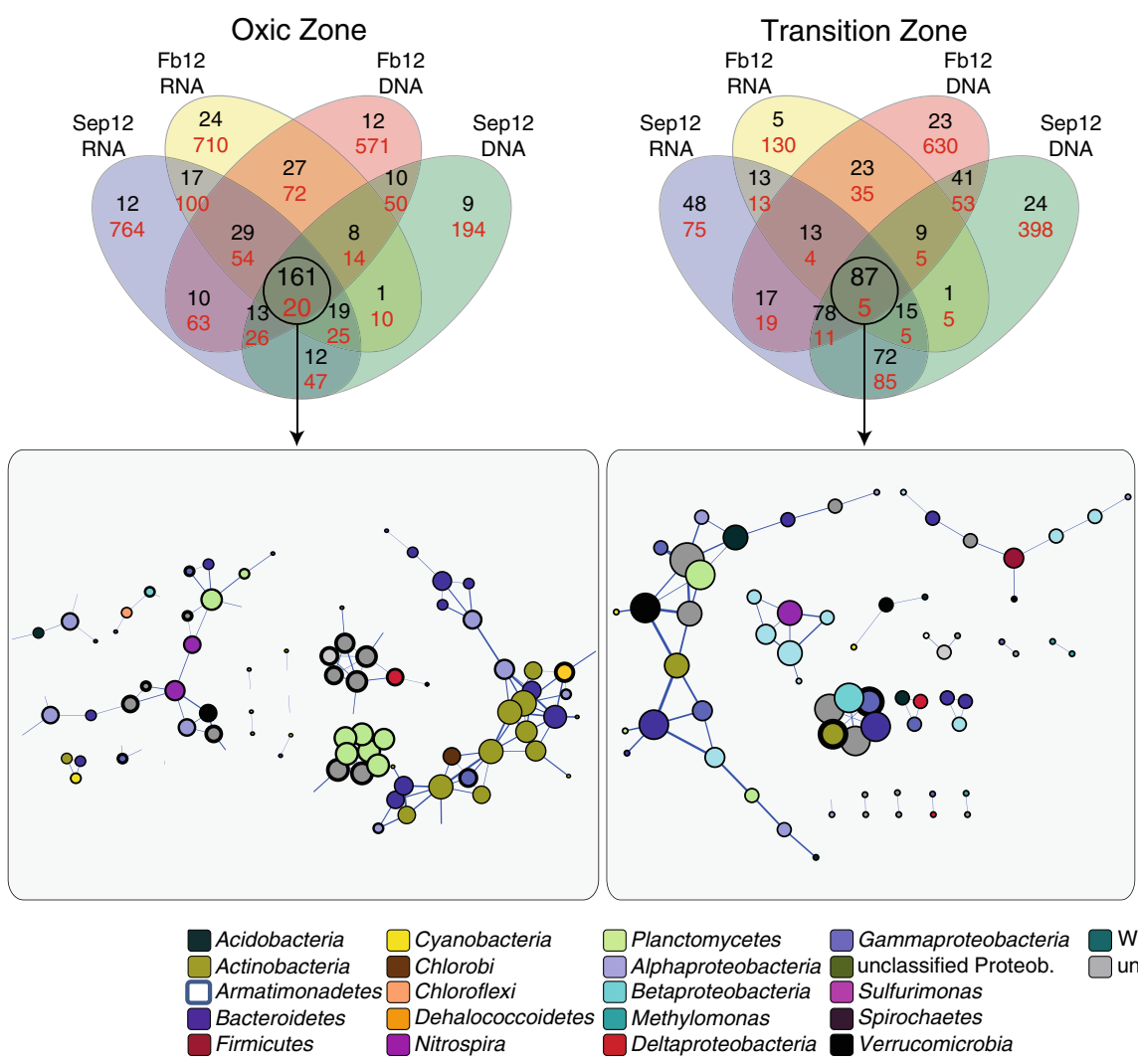

Fig. 3 Venn diagrams showing the distribution of OTUs between active and bulk communities in two campaigns in a oxic, $\mathbf{b}$ transition, and $\mathbf{c}$ anoxic zones. Abundant OTUs were defined as taxa represented by $>15$ sequences (black), whereas rare OTUs were defined as taxa represented by $<15$ sequences $(r e d)$. Network of co-occurring shared OTUs based on

or RNA was analyzed (Fig. 4). Based on clustering at the OTU level and ANOSIM analysis of the bulk community, a significant temporal effect (DS vs. RS) was also observed (Table 2).

Archaeal Community Composition Analysis At an $80 \%$ confidence threshold, all of the reads could be assigned to the Archaea using the SILVA database classifier. Most of all, the nonchimeric and good-quality archaeal amplicons retrieved were affiliated with archaeal phyla, and only two samples from the deepest depths had $7 \%$ unclassified Archaea. All archaeal amplicons retrieved spanned over archaeal lineages covering Thaumarchaeota, Crenarchaeota, and Euryarcheota within both cultured (e.g., marine Crenarchaeota group, Methanosaeta, or Candidatus Methanoregula) and uncultured (e.g., Miscellaneous Crenarchaeotic Group (MCG) and GOM-Arc-I) groups.

At both sampling times, one OTU dominated the DNAand RNA-based communities of the oxic zone, which belonged to the marine group I, tentative ammonia-oxidizing archaea (AOA). AOA were also dominant in the bulk communities in the transition zone, whereas the potentially active archaeal community composition (ACC) was mainly

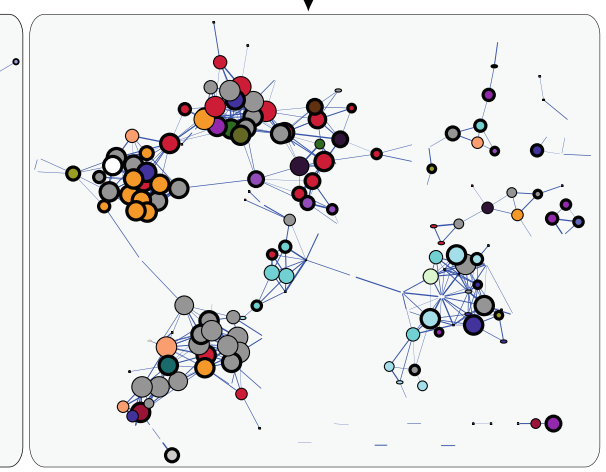

C

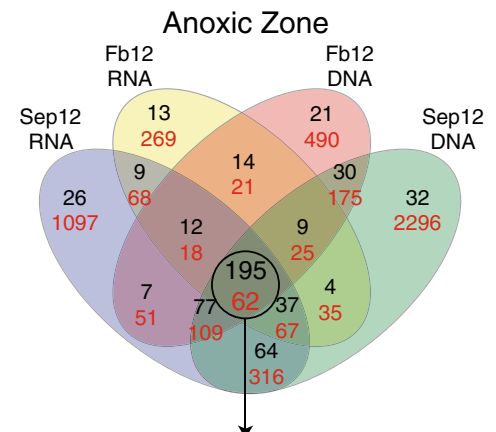

Gammaproteobacteria WS3

unclassified Proteob. $\square$ unclassified Bact.

Sulfurimonas

Spirochaetes

Verrucomicrobia

correlation analyses are shown in the panels below the diagrams. A connection stands for a strong (Pearson $r>0.8$ ) and significant ( $p$ value $0.01)$ correlation. The size of each node is proportionate to the number of connections (i.e., degree)

composed of AOA, Methanomicrobia, and Methanobacteria in the transition zone (Fig. S2J). The DNA- and RNA-based communities thriving in the anoxic zone were dominated by the two methanogens mentioned above and by members of the MCG group.

A Bray-Curtis similarity tree was constructed based on total OTU composition of the 40 archaeal RNA and DNA samples to determine the associations among the communities. Clustering and ANOSIM analyses revealed sampling date as the main grouping factor in structuring the ACC (Fig. S3, Table 2) and nucleic acid type as the second grouping factor. Oxygen had the lowest global structuring effect on ACC, butoxic, and transition water samples clearly segregated from anoxic samples (Fig. S3).

\section{Bacterial Abundance Classification and Overlap} Estimates Bulk and potentially active bacterial taxa from oxic, transition, and anoxic zones were grouped per season (Fig. 3). Venn diagrams of OTUs were constructed to illustrate the number of shared OTUs for the two sampling campaigns based on DNA and RNA. The DNA and RNA samples over the two seasons shared less than $1 \%$ of OTUs in the rare 
February

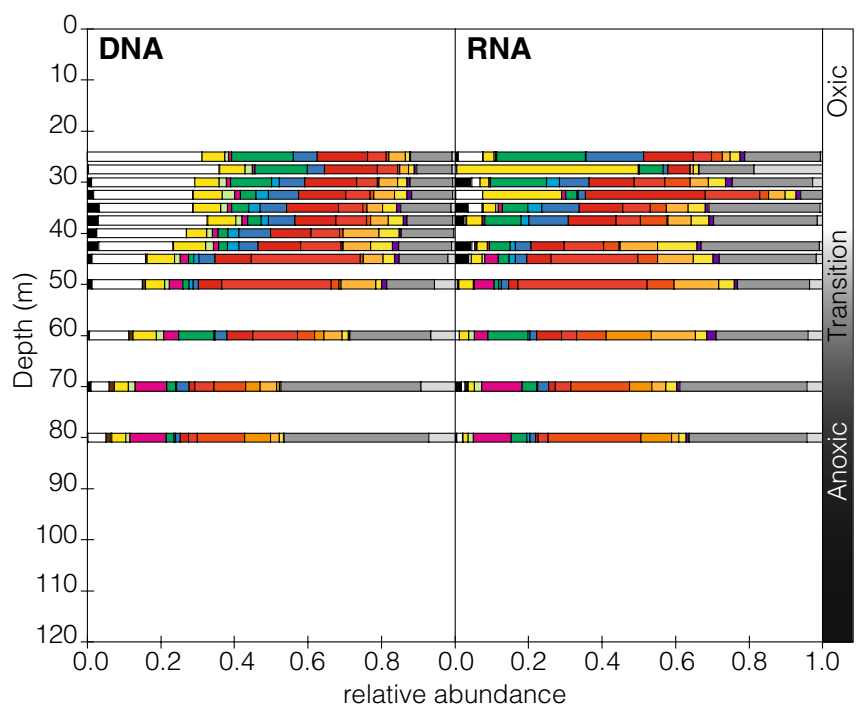

September

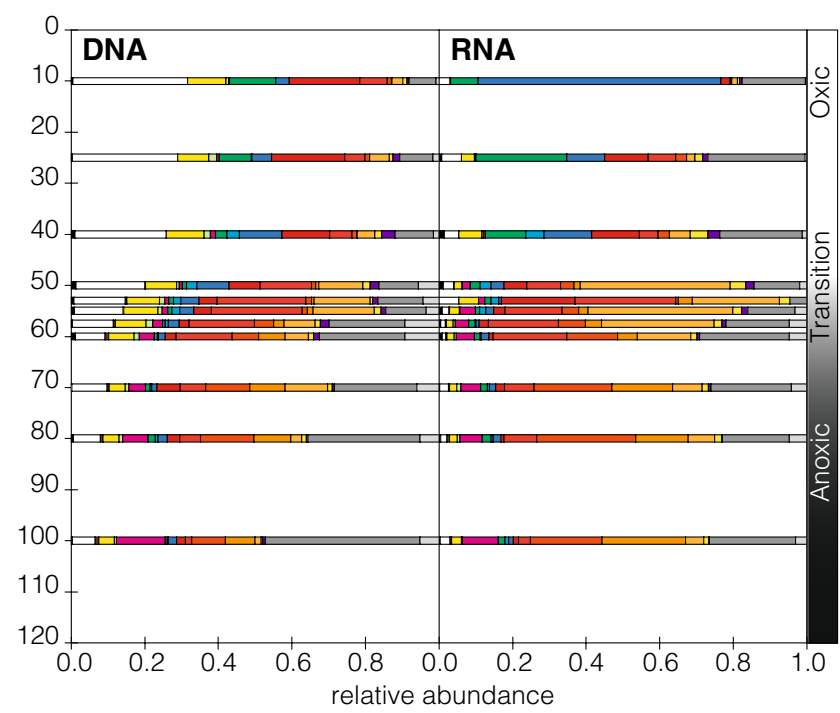

- Alphaprot. $\quad$ Verrucomicrobia

$\square$ Betaprot. $\square$ unclassified Bacteria

$\square$ Deltaprot. $\quad \square$ Other groups

$\square$ Epsilonprot.

$\square$ Gammaprot.

$\square$ uncult. Proteo.

Fig. 4 Taxonomic classification of DNA and RNA bacterial reads at the phylum level in Lake Kivu for the two sampling campaigns (February (left) and September (right)). CFB Bacteroidetes

community. Forty-six, 19, and $35 \%$ of the abundant OTUs were shared in the oxic, transition, and anoxic zone, respectively. Rare species were also found to be specific to the sampling season and nucleic acid-type pool for both subsampled and not-subsampled data (i.e., DNA or RNA).

\section{A}

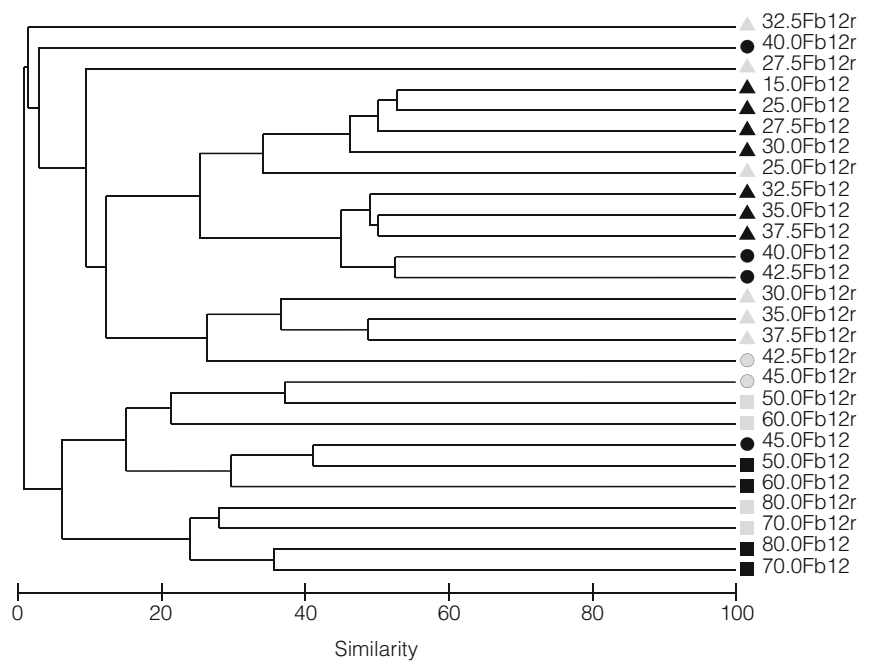

Transform: Square root
Resemblance: S17 Bray Curtis similarity

Fig. 5 Hierarchical clustering of Bray-Curtis similarities of the bacterial community composition at OTU level retrieved by pyrosequencing of both DNA (black symbols) and RNA (gray symbols) nucleic acid pools
Co-occurrence Patterns of Bacteria Co-occurrence patterns of the microbes present in Lake Kivu were only analyzed with the bacterial data set due to the lack of archaeal information at some depths. The co-occurrence patterns for the potentially active core microbiome detected by Venn diagrams were

B

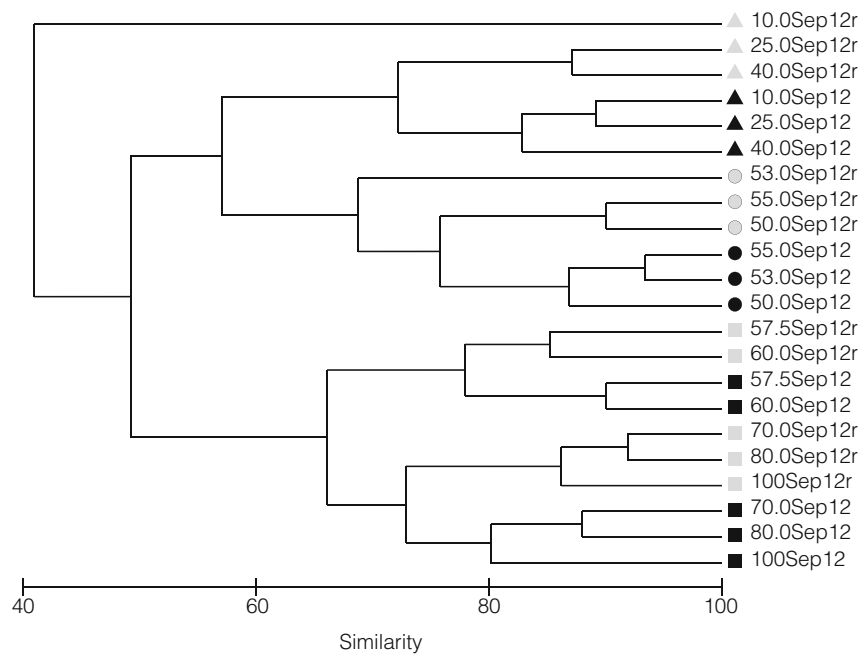

$\Delta$ oxic - DNA Oxic - RNA

transition - DNA transition - RNA

anoxic-DNA anoxic - RNA

in a February and $\mathbf{b}$ September. Samples were grouped according to oxygen content as oxic (triangles), transition (dots), and anoxic (squares) 


\section{A}

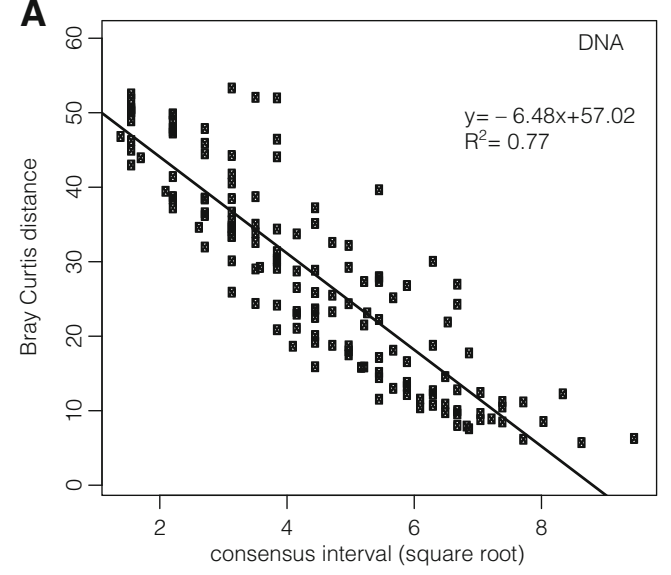

B

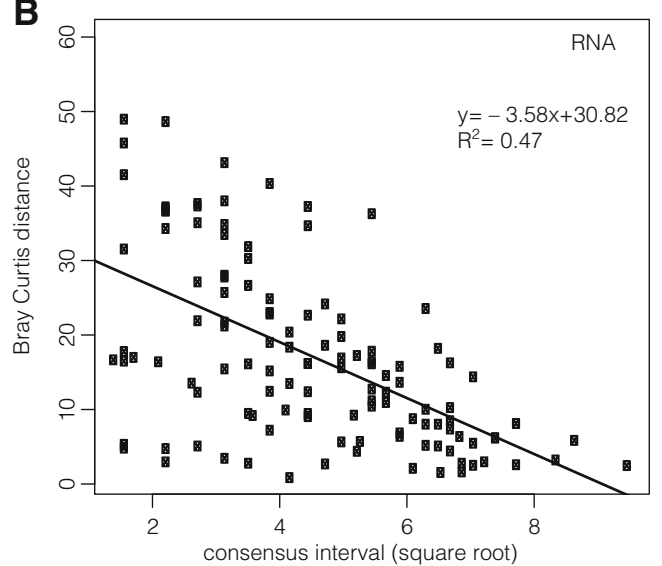

Fig. 6 Quantification of bulk and active bacterial dynamics. Patterns of change (regression of square root of depth lag (consensus interval) on Bray-Curtis distance) of a DNA-based and b RNA-based bacterial communities. The best-fit line and its equation are also shown

Table 2 ANOSIM test on bacterial and archaeal community composition at the OTU level between the three analyzed water compartments

Test for differences between DNA/RNA across all water compartments

\begin{tabular}{lllll} 
& Bacteria & \multicolumn{3}{c}{ Archaea } \\
& $R$ & $p$ & $R$ & $p$ \\
Global test & $\mathbf{0 . 5 3}$ & 0.002 & $\mathbf{0 . 4 9 3}$ & 0.001
\end{tabular}

Test for differences between water compartments across all DNA/RNA

\begin{tabular}{lllll} 
& Bacteria & \multicolumn{3}{c}{ Archaea } \\
& $R$ & $p$ & $R$ & $p$ \\
Global test & $\mathbf{0 . 5 3 7}$ & 0.001 & $\mathbf{0 . 3 5 5}$ & 0.001 \\
Pairwise test & & & & \\
Oxic-transition & $\mathbf{0 . 3 7 0}$ & 0.03 & 0.016 & 0.34 \\
Oxic-anoxic & $\mathbf{0 . 7 3 5}$ & 0.001 & $\mathbf{0 . 5 5 3}$ & 0.001 \\
Transition-anoxic & $\mathbf{0 . 4 5 4}$ & 0.03 & $\mathbf{0 . 4 7 4}$ & 0.001
\end{tabular}

Test for differences between sampling dates across all DNA/RNA

\begin{tabular}{lllll} 
& Bacteria & \multicolumn{3}{c}{ Archaea } \\
Global test & $R$ & $p$ & $R$ & $p$ \\
& $\mathbf{0 . 1 4 5}$ & 0.009 & $\mathbf{0 . 5 0 3}$ & 0.001 \\
\hline
\end{tabular}

Significant values were indicated in bold further assessed using network inference based on strong and significant Pearson correlations $(r>0.8, p<0.01)$. The most complex interaction was found between potentially active bacteria in the anoxic zone. The microbial network for both the oxic and transition zones was composed of 66 nodes (OTUs) with moderate interconnection (2.3 edges per node on average), whereas in the network of the anoxic zone, there were $c a$. three times more nodes with a higher degree of connection (5.6 edges per node on average; Fig. 3). Aside from many unclassified bacteria, interactions between different known taxa were observed. For instance, in the oxic zone, there was a fairly complex subnetwork including Actinobacteria, Bacteroidetes, Alphaproteobacteria, Betaproteobacteria, Gammaproteobacteria, Cyanobacteria, and OPB56. In the transition zone, a subnetwork was observed between OTUs affiliated with $\mathrm{N}$-fixing methane-oxidizing Methylocaldum, hydrogen-oxidizing Hydrogenophaga, and nitrifying bacteria Nitrospira with members of the unclassified proteobacterial class (Fig. 3a). In the anoxic zone, a co-occurrence pattern was observed between sulfate reducers (Desulfobacca, Desulfocapsa, and Desulfobacterium), sulfur oxidizers (Sulfurimonas), and hydrogen oxidizers (Dehalococcoidetes).

\section{Co-occurrence Patterns of Potentially Active Bacteria} and Archaea in the Anoxic Zone Diverse and complex interactions between potentially active bacteria were found in the anoxic zone; therefore, their correlations with archaea were further investigated. The co-occurrence patterns of the potentially active microbiome with a relative abundance higher than $0.5 \%$ were defined using network inference based on strong and significant Pearson correlations $(r>0.8$, $p<0.001)$. The microbial network in the anoxic zone consisted of 31 moderately interconnected nodes ( 2.9 edges per node on average; Fig. S4). A clear interaction between bacterial sulfate reducers, sulfur oxidizers, nitrogen-fixing methanotrophs, archaeal methanogens, and anaerobic methane oxidizers was observed. In addition, another interaction between members of Methanomicrobia, Chlorobicaea, and Syntrophaceae was also observed.

Niche Breadth Comparison Levins' niche breadth was calculated as a proxy to understand how particular taxa relate to their environment. The bulk bacterial community had a strong linear relationship between niche breadth and their relative abundance, while generalist and specialist OTUs in the potentially active bacterial community were more equally distributed within rare and abundant taxa. In addition, niche breadth in the DNA-based bacterial community was higher than in the RNA-based community. Potentially active bacterial OTUs able to develop in either the oxic or anoxic zone were mainly assigned at different taxonomic levels to Burkholderiales, Pseudanabaenaceae, Acidobacteria, and Methylocaldum. In 
contrast, no significant relationship was observed between niche breadth and DNA- and/or RNA-based archaeal relative abundance. Archaeal OTUs detected in both the oxic and anoxic zones were assigned to MGI and Miscellaneous Crenarchaeotic Group. The niche breadth observed for the RNA-based bacterial and archaeal community was narrower than for the DNA-based bacterial and archaeal community (Fig. S5).

Linking Bacterial Communities to Environmental Parameters Variance partitioning analysis (VPA) was performed to quantify the relative contribution of season, depth, and environmental parameters to the taxonomic structure of the bacterial and archaeal communities. The analysis of environmental variables was restricted to a subset of all variables acquired during the field cruises including: $\mathrm{DO}, \mathrm{pH}, \mathrm{NO}_{\mathrm{x}}$, POC, $\mathrm{CH}_{4}$, and Chl- $a$. Clear differences were observed in variance partitioning patterns, if all bacterial OTUs or both abundance categories (abundant/rare) were considered. In all cases, the impact of the environmental parameters was found to be the highest, followed by either season or depth (Fig. 7). The parameters analyzed (depth, season, and environmental variables) in total explained $50 \%$ of the variation observed for the bulk bacterial community, and they explained only $30 \%$ of the variation observed for the potentially active bacterial community. Furthermore, the total relative contributions of variables increased when VPA was performed for only abundant bacterial species, whereas it clearly decreased for rare species. The sum of the parameters analyzed (depth, season, environmental variables) explained $73 \%$ of the variation observed for the bulk archaeal community and only $18 \%$ for the potentially active archaeal community (data not shown).

\section{Discussion}

In the present study, DNA- and RNA-based amplicon pyrosequencing was performed to further investigate the temporal and vertical effects on the bulk and potentially active microbial biosphere of Lake Kivu and to gain a more complete view of the microbial dynamics in Lake Kivu than the one afforded by analyzing either nucleic acid pool alone.

Community Composition at a High Taxonomic Level Due to the strong vertical chemical gradients and zonation of redox reactions with depth, a clear vertical stratification of microbial communities is usually observed for meromictic lakes [48-51]. In spite of the different extraction protocols used, the relative abundances of potentially active and bulk bacterial and archaeal communities were mostly similar at the phylum level, with some notable exceptions. These differences were mostly observed in the oxic zone. For instance, Actinobacteria were highly dominant in the bulk bacterial community of surface waters (around $30 \%$ ); however, this dominance was lower in the potentially active community, as previously shown in a eutrophic lake [52]. Actinobacteria might experience lower
Fig. 7 Variation partitioning of bacterial community composition. The figure depicts the fractions (\%) of variation in bacterial community composition that are explained by environmental parameters $(\mathrm{pH}+$ $\mathrm{DO}+\mathrm{NO}_{\mathrm{x}}+\mathrm{POC}+\mathrm{CH}_{4}+\mathrm{Chl}$, depth, and season or that remain unexplained for bulk and active bacterial communities. $U$ unexplained
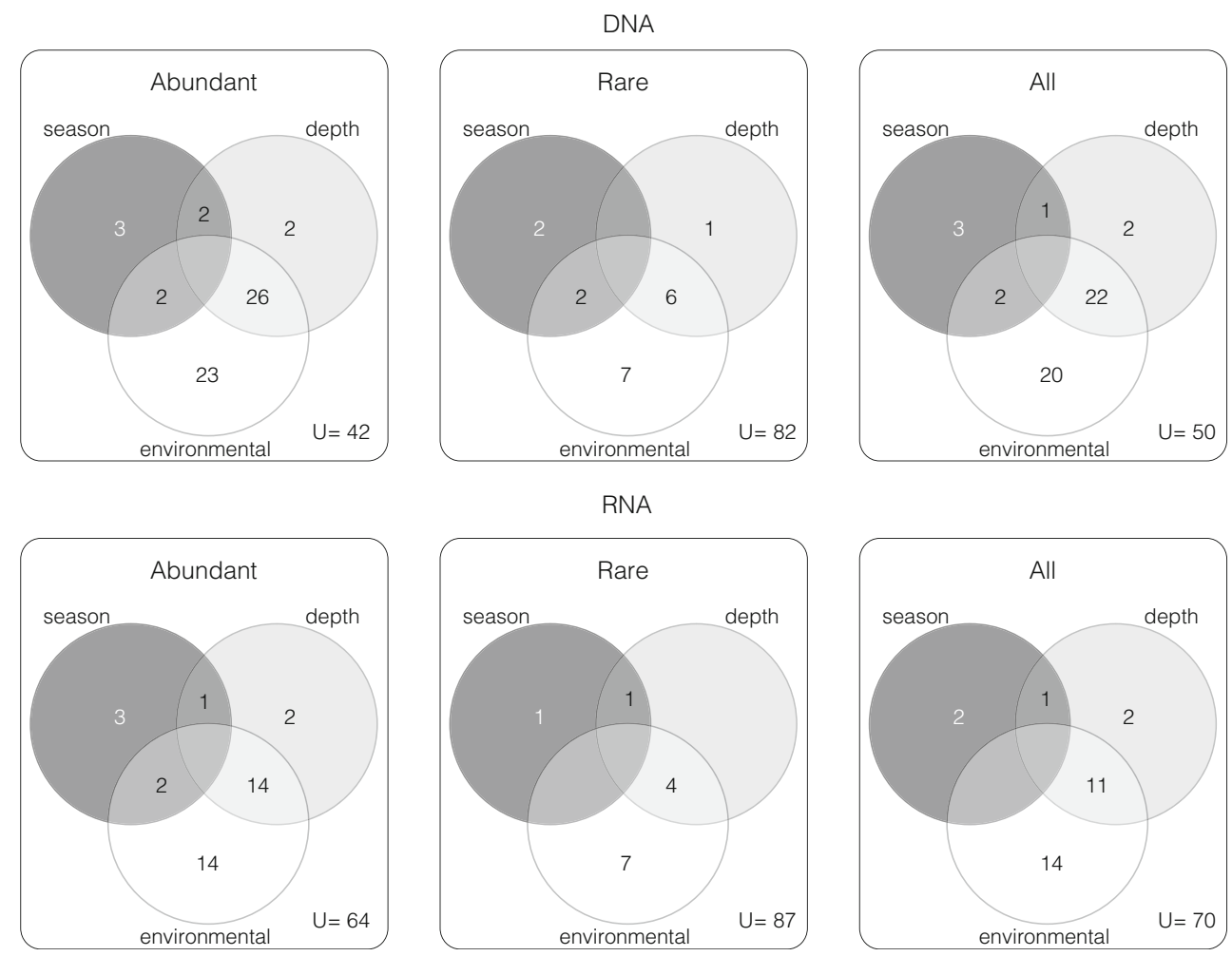
mortality rates than other bacterial lineages due to the resistance to protozoan grazing [53] and small cell size [54]. Therefore, Actinobacteria might not require rapid growth to maintain high cell densities in the water column [55]. This might be also due to the difference in lysis methods used for DNA and RNA extraction. Bacteroidetes (CFB) and Planctomycetes were substantial components of potentially active BCC in the oxic waters of Lake Kivu in the rainy and dry season, respectively (Fig. 4). Many studies have reported high relative abundance of Bacteroidetes or Planctomycetes following algal blooms [56-60]. Both phyla are known to be present and attached to aggregates, and they have various extracellular enzymes that can degrade complex organic molecules and give a competitive advantage with regards to other microbial groups [61-63]. Presence of a high percentage of these two phyla in different seasons might be due to the competition between these two phyla for organic matter or dominance of different phytoplankton species in two seasons, as mainly a higher dominance of diatoms was observed in the DS and Cyanobacteria were more dominant in the RS (Fig. 4; [23]). Besides, Cyanobacteria represent a big fraction of the active microbial community in oxic and illuminated waters (Fig. 4 and Fig. S2) due to their oxic photoautotrophic metabolism. A recent study done in Lake Kivu suggested that a variety of ecological niches of heterotrophic bacteria can be supported by the diversity of molecules excreted by the phytoplankton community [64]. Detection of a low abundance of potentially active Planctomycetes-affiliated sequences in the anoxic zone supported the idea that members of this group have anaerobic metabolic abilities, as suggested by previous studies showing that they rely on carbohydrate fermentation and sulfur reduction for growth and survival under anaerobic conditions [65]. Furthermore, sequences affiliated to Chlorobi phylum were recovered from both nucleic acid pools of either oxic or anoxic waters and sampling campaigns. Their recovery from oxic waters is an interesting feature and deserves further investigations, but recent evidences pointed toward new Chlorobi representatives able to develop under aerobic conditions performing photoheterotrophic metabolisms [66, 67].

Furthermore, higher abundance of AOA was shown in the bulk community in comparison to the potentially active community. Such discrepancy between DNA- and RNA-based studies of surface waters has also been observed in freshwater ecosystems [4, 68]. The denitrification genes nirK and nosZ were slightly higher in the oxic zone than in the anoxic zone (Fig. 2). Previously, growth of facultative anaerobic denitrifiers in aerobic environments was demonstrated, which suggests a wider distribution of potential denitrifiers in the aerobic growth conditions of this lake $[69,70]$. The good correlation found between nirK and nos $Z$ genes might be due to the fact that these genes are usually located in the same operon [71, 72].

Detection of highly abundant potentially active Nitrospira in the transition zone confirmed a previous study of the nitrite- oxidizing community in the transition zone of Lake Kivu (Figs. 4 and S2D; [20]). The $\mathrm{CH}_{4}$ oxidation peak in the transition zone was also strongly correlated with the relative abundance of active methanotrophs and abundance of $p m o A$ gene $(p<0.05$; data not shown). Detection of potentially active Methylococcales and Methyloversatilis indicates aerobic $\mathrm{CH}_{4}$ oxidation as the main process preventing $\mathrm{CH}_{4}$ from escaping to the atmosphere (Fig. S2E). The co-occurrence of $\mathrm{CH}_{4}$ oxidizing Methylocaldum and hydrogen-oxidizing Hydrogenophaga supports recent findings of $\mathrm{CH}_{4}$ consumption in $\mathrm{O}_{2}$-limiting conditions by Methylocaldum, leading to the release of several organic molecules (e.g., acetate, lactate, succinate, and hydrogen) that can be used by Hydrogenophaga [73].

Several archaeal groups able to produce $\mathrm{CH}_{4}$ have also been detected in both DNA and RNA-based communities mainly in the anoxic waters. Indeed, their presence even in the transition zone is consistent with recent studies that showed the presence of potentially active methanogens in the oxygenated water column of an oligotrophic lake attached to photoautotrophic microbes that might be enabling aerobic growth and supply of methanogenic substrates $[74,75]$. However, the presence of acetoclastic methanogens (Methanosarcinales) in the oxic-anoxic transition zone might also indicate the presence of syntrophy between methanogenic and fermentative microbes, through the occurrence of a coupled mutualistic interaction between hydrogen-/formate-producing and hydrogen-/formate-using microorganisms [76]. A consistent relationship between uncultured OTUs of Methanomicrobia, Chlorobicaeae, and Syntrophaceae was also observed in the anoxic zone (Fig. S3), which could indicate the presence of syntrophic relationships between these microbes in hydrocarbon or complex high molecular weight compound degradation, as previously shown in the sediments of the River Tyne [77].

Network analysis revealed a complex interaction between active Dehalococcoidetes, sulfate-reducing bacteria (SRB; Desulfucapsa, Desulfobacca), and sulfur-oxidizing bacteria (SOB; Sulfurimonas, Sulfuricurvum) in the anoxic zone (Fig. 3c). The co-occurrence of active SOB and SRB in the anoxic zone may further suggest the presence of an active yet cryptic sulfur cycle [20]. It has been evidenced that Dehalococcoidetes may have a nutritional dependence on other organisms [78, 79]; the co-occurrence of this active but rare bacterial class with SRB might thus be linked to its role in hydrocarbon degradation (Fig. 3c). Recent investigations have described complex interactions between Dehalococcoides, $\mathrm{SRB}$, and methanogens depending on their metabolic activities and nutrient (e.g., hydrogen, acetate) or vitamin (e.g., B12) concentrations [80], suggesting their multiple metabolic capabilities.

Bulk Versus Potentially Active Community Structure Although the samples analyzed had mostly similar taxonomic characterization at the phylum level, clustering analysis at the OTU level highlighted the importance of which nucleic acid 
pool (i.e., DNA or RNA) was analyzed. The presence of sequences exclusively found in one of the two nucleic acid pools suggests that using both nucleic acids provides a more complete overview of the microbial diversity present in a given environment since on average, only $20 \%$ of the OTUs (18$22 \%$ ) were shared per DO zone and per season. As previously suggested [81], sequences found only in the DNA pool might be related to metabolically less active, yet abundant populations, whereas sequences detected only in RNA are associated with active members of the community but may be present in relatively low numbers. The type of populations associated with shared and unshared sequences could be the result of differences in their respective overall abundance and/or a reflection on the overall metabolic status of a population within a given OTU. The detection of taxa in only one pool and not in the other can also be due to insufficient pyrosequencing in the effort to reveal complete diversity, and this had obviously more effect on the rare community.

Inactive cells are seen as a potential seed bank, which enables a rapid community adaptation to changing environments, so that the overall community always prevails [82, 83]. DNA and RNA profiles were found to be more similar in the anoxic zone than in the oxic or transition zones. The results agree with the fact that anaerobic processes are less energetic than aerobic respiration, thus suggesting slow growth rates in the anoxic water compartment of Lake Kivu. Besides, the anoxic water compartment of Lake Kivu was also more diverse in types as pointed out by the richness estimations $(p<0.02)$. It was previously suggested that anoxic environments maintain a higher diversity of energetic pathways and that this complexity permits the retention of higher metabolic and thus ecological diversity [3, 84].

Abundant and Rare Taxa Both bulk and potentially active microbial communities present in the water column of Lake Kivu comprised few very abundant OTUs and a huge number of low-abundant and rare OTUs (data not shown). The fact of even recovering a long tail of rare low-abundant OTUs within the potentially active members of the microbial community evidenced the existence of an active rare biosphere in Lake Kivu or a pool of dormant microbes with enough RNA pool to recover from this situation when necessary [6]. Venn diagrams revealed that bulk and potentially active bacterial communities shared a high fraction of those highly abundant taxa. In contrast, rare OTUs were detected in a high proportion exclusively in either bulk or potentially active bacterial communities. As suggested for estuarine and coastal ocean waters, the metabolically active rare biosphere of Lake Kivu might be potentially important for the functioning and the temporal dynamics of microbial communities as they shift between seasons [13-15].

Levins' niche width was used to classify the taxa retrieved in Lake Kivu as generalists or specialists based on the environmental conditions in which they developed but not directly on their intrinsic biological properties [85]. Most bacterial taxa identified as generalists were abundant, whereas those identified as specialists were more likely to be rare (mainly in the bulk community), and this pattern was less evident for the potentially active community. Such a significant relationship could not be observed for archaeal taxa, which might be due to missing depths in our analysis. The detection of some OTUs in either bulk or potentially active communities in both oxic and anoxic zones might reflect some metabolic flexibility and capacity to cope with the different redox conditions present in the lake's water column.

Moreover, variation partitioning analyses were performed to assess the contributions of depth, season, and environmental parameters to microbial community structure. The pool of environmental parameters analyzed here could explain the highest part of the variation in bacterial communities. The results of this study showed that DO had the most significant effect in shaping the BCC, as shown previously [86]. In addition to $\mathrm{DO}$, bacterial community variance was also significantly related to $\mathrm{pH}$ in the lake. Any significant deviation in environmental $\mathrm{pH}$ should impose stress on single-cell organisms, since intracellular $\mathrm{pH}$ of most microorganisms is usually within $1 \mathrm{pH}$ unit of neutral $[87,88]$. The significant effect of $\mathrm{pH}$ on the BCC was also shown in a range of aquatic environments [88]. The overall number of environmental variations that could explain the presence of taxa was also higher for abundant taxa in comparison to rare taxa. This might indicate that abundant taxa are sufficient to describe the mechanisms underlying the beta-diversity [6]. However, it is possible that rare species were more affected by environmental parameters such as concentrations of micronutrients, hydrocarbons, as well as stochastic dispersal, immigration, and predation, which were not measured in this study and thus not taken into account in the statistical analysis [6]. Furthermore, a higher degree of the variation was explained for the bulk BCC than for the potentially active BCC. It might indicate that the seed bank likely represents the species pool of the complex water habitat and enables the shift in rapidly changing environments and also potentially stabilize ecosystem.

\section{Conclusions}

Combination of complementary methods (16S rRNA, rDNA pyrosequencing, and qPCR) provided insights into the active community and functional genes present in Lake Kivu, where biogeochemical cycling appeared to be functioning synergistically. Detection of key players in biogeochemical cycles in the various water layers were also supported by the vertical chemical gradients. The experimental evaluation suggests that the quantification of functional genes by qPCR was mostly in agreement with the pyrosequencing of complex microbial 
communities. This study showed that rare taxa (mainly specialists), especially in the anoxic zone, cannot solely be characterized as a seed bank or dormant cells in Lake Kivu but that a significant portion of the rare community is potentially active, which supports the results of various studies conducted in freshwater and marine environments $[13,14]$. However, the impact of environmental parameters measuredwas stronger for the generalists (mainly abundant taxa), which indicates the presence of different ecological rules for different groups.

Acknowledgments In addition to the authors of this paper, the Lake Kivu consortium includes the following individuals: S. Bouillon (KatholiekeUniversiteit Leuven), M.-V. Commarieu, F. A. E. Roland (Université de Liège), B. Leporcq, K. de Saedeleer (Université de Namur), A. Anzil, S. Vanderschueren, C. Michiels (UniversitéLibre de Bruxelles), and G. Alunga (DR Congo team). The consortium gratefully acknowledges the Rwanda Energy Company and Michel Halbwachs for free access to their industrial platform off Gisenyi. R. Trias (Institut de Physique du Globe de Paris, France) is acknowledged for supplying some of the qPCR-positive controls. This work was funded by the Fonds National de la RechercheScientifique (FNRS) under the MICKI (Microbial diversity and processes in Lake Kivu) project and the Belgian Federal Science Policy Office EAGLES (East African Great Lake Ecosystem Sensitivity to changes, SD/AR/02A) project, and contributes the European Research Council starting grant project AFRIVAL (African river basins: Catchment-scale carbon fluxes and transformations, 240002).

Conflict of Interest The authors declare no conflict of interest.

\section{References}

1. Casamayor EO, Llirós M, Picazo A, Barberán CM, Borrego CM, Camacho A (2012) Contribution of deep dark fixation processes to overall CO2 incorporation and large vertical changes of microbial populations in stratified karstic lakes. Aquat Sci 74(1):61-75

2. Eiler A, Heinrich F, Bertilsson S (2012) Coherent dynamics and association networks among lake bacterioplankton taxa. ISME J 6: 330-342

3. Lehours AC, Bardot C, Thenot A, Debroas D, Fonty G (2005) Anaerobic microbial communities in Lake Pavin, a unique meromictic lake in France. Appl Environ Microbiol 71:7389-7400

4. Logue JB, Lindström ES (2010) Species sorting affects bacterioplankton community composition as determined by $16 \mathrm{~S}$ rDNA and 16S rRNA fingerprints. ISME J 4:729-738

5. Van der Gucht K, Cottenie K, Muylaert K, Vloemans N, Cousin S, Declerck S et al (2007) The power of species sorting: local factors drive bacterial community composition over a wide range of spatial scales. Proc Natl Acad Sci USA 104:20404-20409

6. Lennon JJ, Jones SE (2011) Microbial seed banks: the ecological and evolutionary implications of dormancy. Nat Rev 9:119-130

7. Huber JA, Welch DBM, Morrison HG, Huse SM, Neal PR, Butterfield DA, Sogin ML (2007) Microbial population structures in the deep marine biosphere. Science 318:97-100

8. Huber JA, Cantin HV, Huse SM, Mark Welch DB, Sogin ML, Butterfield DA (2010) Isolated communities of Epsilonproteobacteria in hydrothermal vent fluids of the Mariana Arc sea mounts. FEMS Microbiol Ecol 73:538-549

9. Sogin ML, Morrison HG, Huber JA et al (2006) Microbial diversity in the deep sea and the underexplored 'rare biosphere'. Proc Natl Acad Sci USA 103:12115-12120
10. Pedrós-Alió C (2006) Marine microbial diversity: can it be determined? Trends Microbiol 14:257-263

11. Polymenakou PN, Lampadariou N, Mandalakis M, Tselepides A (2009) Phylogenetic diversity of sediment bacteria from the southern Cretan margin, Eastern Mediterranean Sea. Syst Appl Microbiol $32: 17-26$

12. Lanzén A, Jørgensen SL, Bengtsson MM, Jonassen I, Øvreås L, Urich T (2011) Exploring the composition and diversity of microbial communities at the Jan Mayen hydrothermal vent field using RNA and DNA. FEMS Microbiol Ecol 77:577-589

13. Campbell BJ, Yu L, Heidelberg JF, Kirchman DL (2011) Activity of abundant and rare bacteria in a coastal ocean. Proc Natl Acad Sci USA 108:12776-12781

14. Campbell BJ, Kirchman DL (2013) Bacterial diversity, community structure and potential growth rates along an estuarine salinity gradient. ISME J 7:210-220

15. Jones SE, Lennon JT (2010) Dormancy contributes to the maintenance of microbial diversity. Proc Natl Acad Sci USA 107:58815886

16. Moeseneder MM, Arrieta JM, Herndl GJ (2005) A comparison of DNA- and RNA-based clone libraries from the same marine bacterioplankton community. FEMS Microbiol Ecol 51(3):341-52

17. Schmid M, Halbwachs M, Wehrli B, Wüest A (2005) Weak mixing in Lake Kivu: new insights indicate increasing risk of uncontrolled gas eruption. Geochem Geophys Geosyst 6, Q07009

18. Borges AV, Abril G, Delille B, Descy JP, Darchambeau F (2011) Diffusive methane emissions to the atmosphere from Lake Kivu (Eastern Africa). J Geophys Res 116, G03032

19. Pasche N, Schmid M, Vasquez F, Schubert CJ, Wüest A, Kessler JD, Pack MA, Reeburgh WS, Bürgmann H (2011) Methane sources and sinks in Lake Kivu. J Geophys Res 116, G03006

20. İnceoğlu Ö, Llirós M, Garcia-Armisen T, Crowe SA, Michiels C, Darchambeau F, Descy JP, Servais P Distribution of bacteria and archaea in meromictic tropical Lake Kivu (Africa). Aquat Microb Ecol. doi:10.3354/ame01737. In press.

21. Llirós M, Gich F, Plasencia A, Auguet JC, Darchambeau F, Casamayor EO, Descy JP, Borrego C (2010) Vertical distribution of ammonia-oxidizing Crenarchaeota and methanogens in the epipelagic waters of Lake Kivu (Rwanda-Democratic Republic of the Congo). Appl Environ Microbiol 76(20):6853-6863

22. Darchambeau F, Sarmento H, Descy J-P (2014) Primary production in a tropical large lake: the role of phytoplankton composition. Sci Total Environ 473-474:178-188

23. Sarmento H, Isumbisho M, Descy JP (2006) Phytoplankton ecology of Lake Kivu. J Plankton Res 28:815-829

24. Isumbisho M, Sarmento H, Kaningini B, Micha JC, Descy JP (2006) Zooplankton of Lake Kivu, East Africa, half a century after the Tanganyika sardine introduction. J Plankton Res 28:971-989

25. Schmid M, Wüest A (2012) In: Descy JP, Darchambeau F, Schmid $\mathrm{M}$ (eds) Stratification mixing and transport processes in Lake Kivu. Springer, Lake Kivu, pp 13-30

26. Wright JJ, Konwar KM, Hallam SJ (2012) Microbial ecology of expanding oxygen minimum zones. Nat Rev Microbiol 10(6):381394

27. Standing Committee of Analysts (1981) Methods for the examination of waters and associated materials Ammonia in waters. HMSO, London

28. EatonE, Archie AE, Rice EW, Clesce LS (2012) Standard Methods for the Examination of Water Wastewater, APHA 22nd Edition

29. Miranda KM, Espey MG, Wink DA (2001) A rapid, simple spectrophotometric method for simultaneous detection of nitrate and nitrite. Nitric Oxide 5(1):62-71

30. Cline JD (1969) Spectrophotometric determination of hydrogen sulfide in natural waters. Limnol Oceanogr 14:454-458 
31. Llirós M, Casamayor E, Borrego CM (2008) High archaeal richness in the water column of a freshwater sulfurous karstic lake along an inter-annual study. FEMS Microbiol Ecol 66:331-342

32. Frias-Lopez J, Shi Y, Tyson GW, Coleman ML, Schuster SC, Chisholm SW, Delong EF (2008) Microbial community gene expression in ocean surface waters. Proc Natl Acad Sci USA 105: 3805-10

33. Costello AM, Lidstrom ME (1999) Molecular characterization of functional and phylogenetic genes from natural populations of methanotrophs in lake sediments. Appl Environ Microbiol 65(11): 5066-5073

34. Luton PE, Wayne JM, Sharp RJ, Riley PW (2002) The mcrA gene as an alternative to $16 \mathrm{~S}$ rRNA in the phylogenetic analysis of methanogen populations in landfill. Microbiology 148:3521-3530

35. Henry S, Bru D, Stres B, Hallet S, Philippot L (2006) Quantitative detection of the nosZ gene, encoding nitrous oxide reductase, and comparison of the abundances of 16S rRNA, narG, nirK, and 1 genes in soils. Appl Environ Microbiol 72(8):5181-5189

36. Development Core Team R (2011) R: A language and environment for statistical computing R Foundation for Statistical Computing. Austria, Vienna, Available at: http://www.R-project.org

37. Callaway TR, Dowd SE, Wolcott RD, Sun Y, McReynolds JL et al (2009) Evaluation of the bacterial diversity in cecal contents of laying hens fed various molting diets by using bacterial tag encoded FLX amplicon pyrosequencing. Poult Sci 88:298-302

38. Dowd SE, Wolcott RD, Sun Y, McKeehan T, Smith E, Rhoads D (2008) Polymicrobial nature of chronic diabetic foot ulcer biofilm infections determined using bacterial tag encoded FLX amplicon pyrosequencing (bTEFAP). PLoS One 3, e3326

39. Edgar RC, Haas BJ, Clemente JC, Quince C, Knight R (2011) UCHIME improves sensitivity and speed of chimera detection. Bioinformatics (Oxford, England) 27(16):2194-2200

40. Schloss PD, Westcott SL, Ryabin T, Hall JR, Hartmann M et al (2009) Introducing Mothur: open-source, platform-independent, community-supported software for describing and comparing microbial communities. Appl Environ Microbiol 75:7537-7541

41. Clarke KR, Gorley RN (2006) PRIMER V6: usermanual/Tutorial Plymouth. PRIMER-E, UK

42. Levins R (1968) Evolution in changing environments. Princeton University Press, Princeton

43. Logares R, Lindström ES, Langenheder S, Logue JB, Paterson H, Laybourn-Parry J, Rengefors K, Tranvik L, Bertilsson S (2013) Biogeography of bacterial communities exposed to progressive long-term environmental change. ISME J 7(5):937-48

44. Faust K, Sathirapongsasuti JF, Izard J, Segata N, Gevers G, Raes J, Huttenhower C (2012) Microbial co-occurrence relationships in the human microbiome. PLoS Comput Biol 8(7), e1002606

45. Shannon P, Markiel A, Ozier O, Baliga NS, Wang JT, Ramage D, Amin N, Schwikowski B, Ideker T, Warnecke F, Sommaruga R, Sekar R, Hofer JS, Pernthaler J (2003) Cytoscape: a software environment for integrated models of biomolecular interaction networks. Genome Res 13:2498-2503

46. Peres-Neto PR, Legendre P, Dray S, Borcard D (2006) Variation partitioning of species data matrices: estimation comparison of fractions. Ecology 87:2614-2625

47. Oksanen J, Blanchet FG, Kindt R, Legendre P, Minchin PR, O'Hara RB, Simpson GL (2012) vegan: Community Ecology Package R package version 20-5 http://CRAN.R-project.org/package=vegan

48. Dimitriu PA, Pinkart HC, Peyton BM, Mormile MR (2008) Spatial and temporal patterns in the microbial diversity of a meromictic soda lake in Washington State. Appl Environ Microbiol 74:48774888

49. Koizumi Y, Kojima H, Oguri K, Kitazato H, Fukui M (2004) Vertical and temporal shifts in microbial communities in the water column and sediment of saline meromictic Lake Kaiike (Japan), as determined by a $16 \mathrm{~S}$ rDNA-based analysis, and related to physicochemical gradients. Environ Microbiol 6:622-637

50. Lentini V, Gugliandolo C, Maugeri TL (2012) Vertical distribution of Archaea and Bacteria in a meromictic lake as determined by fluorescent in situ hybridization. Curr Microbiol 64:66-74

51. Newton RJ, Jones SE, Eiler A, McMahon KD, Bertilsson S (2011) A guide to the natural history of freshwater lake bacteria. Microbiol Mol Biol Rev 75(1):14-49

52. Kolmonen E, Sivonen K, Rapala J, Haukka K (2004) Diversity of Cyanobacteria and heterotrophic bacteria in cyanobacterial blooms in Lake Joutikas, Finland. Aquat Microb Ecol 36:201-211

53. Hahn MW, Lünsdorf H, Wu Q, Schauer M, Höfle MG, Boenigk J, Stadler P (2003) Isolation of novel ultramicrobacteria classified as Actinobacteria from five freshwater habitats in Europe and Asia. Appl Environ Microbiol 69:1442-1451

54. Kemp PF, Lee S, LaRoche J (1993) Estimating the growth rate of slowly growing marine bacteria from RNA content. Appl Environ Microbiol 59:2594-2601

55. Pernthaler J, Posch T, Simek K, Vrba J, Pernthaler A, Glöckner FO, Nübel U, Psenner R, Amann R (2001) Predator-specific enrichment of actinobacteria from a cosmopolitan freshwater clade in mixed continuous culture. Appl Environ Microbiol 67:2145-2155

56. Brümmer IHM, Felske ADM, Wagner-Döbler I (2004) Diversity and seasonal changes of uncultured Planctomycetales in river biofilms. Appl Environ Microbiol 70:5094-5101

57. Mary I, Cummings DG, Biegala IC, Burkill PH, Archer SD, Zubkov MV (2006) Seasonal dynamics of bacterioplankton community structure ata coastal station in the western English Channel. Aquat Microb Ecol 41:119-126

58. Pinhassi J, Sala MM, Havskum H, Peters F, Guadayol Ò, Malits A, Marrasé C (2004) Changes in bacterioplankton composition under different phyto-plankton regimens. Appl Environ Microbiol 70: 6753

59. Pizzetti I, Fuchs BM, Gerdts G, Wichels A, Wiltshire KH, Amann R (2011) Temporal variability of coastal Planctomycetes clades at Kabeltonne station, North Sea. Appl Environ Microbiol 77:50095017

60. Tadonléké RD (2007) Strong coupling between natural Planctomycetes and changes in the quality of dissolved organic matter in freshwater samples. FEMS Microbiol Ecol 59:543-555

61. Bauer M, Kube M, Teeling H, Richter M, Lombardot T, Allers E, Würdemann CA, Quast C, Kuhl H, Knaust F, Woebken D, Bischof K, Mussmann M, Choudhuri JV, Meyer F, Reinhardt R, Amann RI, Glöckner FO (2006) Whole genome analysis of the marine Bacteroidetes 'Gramellaforsetii' reveals adaptations to degradation of polymeric organic matter. Environ Microbiol 8:2201-2213

62. DeLong EF, Franks DG, Alldredge AL (1993) Phylogenetic diversity of aggregate-attached vs. free-living marine bacterial assemblages. Limnol Oceanogr 38:924-934

63. Grossart HP, Levold F, Allgaier M, Simon M, Brinkhoff T (2005) Marine diatom species harbour distinct bacterial communities. Environ Microbiol 7:860-873

64. Morana C, Sarmento H, Descy JP, Gasol JM, Borges AV, Bouillon S, Darchambeau F (2014) Production of dissolved organic matter by phytoplankton and its uptake by heterotrophic prokaryotes in large tropical lakes. Limnol Oceanogr 59(4):1364-1375

65. Elshahed MS, Youssef NH, Luo Q, Najar FZ, Roe BA, Sisk TM, Bühring SI, Hinrichs KU, Krumholz LR (2007) Phylogenetic and metabolic diversity of Planctomycetes from anaerobic, sulfide- and sulfur-rich Zodletone Spring, Oklahoma. Appl Environ Microbiol 73(15):4707-16

66. Bryant DA, Liu Z, Li T, Zhao F, Garcia Costas AM, Klatt CG (2012) Comparative and functional genomics of anoxygenic green bacteria from the taxa Chlorobi, Chloroflexi, and Acidobacteria. In: Burnap RL, Vermaas W (eds) Functional Genomics and Evolution of Photosynthetic Systems, vol 35. Springer, Dordrecht, pp 47-102 
67. aаaаaаaаaаaаa

68. Troussellier M, Schäfer H, Batailler N, Bernard L, Courties L, Lebaron P, Muyzer G, Servais P, Stackebrandt E, Vives-Rego J (2002) Bacterial activity and genetic richness along an estuarine gradient (Rhone River plume, France). Aquat Microb Ecol 28:1324

69. Hannig M, Braker G, Dippner J, Jürgens K (2006) Linking denitrifier community structure and prevalent biogeochemical parameters in the pelagial of the central Baltic Proper (Baltic Sea). FEMS Microbiol Ecol 57:260-271

70. Tiedje JM (1998) Ecology of denitrification and dissimilatory nitrate reduction to ammonium. In: Zehnder AJB (ed) Biology of anaerobic microorganisms. John Wiley Sons, New Yorkpp, pp 179-244

71. Richardson R, Felgate H, Watmough N, Thomson A, Baggs E (2009) Mitigating release of the porent greenhouse gas N2O from the nitrogen cycle could enzymic regulation hold the key? Trends Biotechnol 27(7):388-397

72. Jones CM, Stres M, Rosenquist M, Hallin S (2008) Phylogenetic analysis of nitrite, nitric oxide and nitrous oxide respitory enzymes reveal a complex evolutionary history for denitrification. Mol Biol Evol 25(9):1955-1966

73. Kalhuzhnaya M (2013) Highly efficient methane biocatalysis revealed in a methanotrophic bacterium. Nat Commun 4:2785

74. Grossart HP, Frindte K, Dziallas C, Eckert W, Tang KW (2011) Microbial methane production in oxygenated water column of an oligotrophic lake. Proc Natl Acad Sci USA 108(49):19657-61

75. Tang KT, McGinnis DF, Frindte K, Brüchert V, Grossart H-P (2014) Paradox reconsidered: methane oversaturation in welloxygenated lake waters. Limnol Oceanogr 59:275-284

76. Sieber JR, McInerney MJ, Gunsalus RP (2012) Genomic insights into syntrophy: the paradigm for anaerobic metabolic cooperation. Annu Rev Microbiol 66:429-52

77. Gray ND, Sherry A, Grant RJ, Rowan AK, Hubert CR, Callbeck CM, Aitken CM, Jones DM, Adams JJ, Larter SR, Head IM (2011) The quantitative significance of Syntrophaceae and syntrophic partnerships in methanogenic degradation of crude oil alkanes. Environ Microbiol 13(11):2957-75
78. He J, Holmes VF, Lee PKH, Alvarez-Cohen L (2007) Influence of vitamin B12 and cocultures on the growth of Dehalococcoides isolates in defined medium. Appl Environ Microbiol 73:2847-2853

79. Krzmarzick MJ, McNamara PJ, Crary BB, Novak PJ (2013) Abundance and diversity of organohalide-respiring bacteria in lake sediments across a geographical sulfur gradient. FEMS Microbiol Ecol 84(2):248-58

80. Futagami T, Okamoto F, Hashimoto H, Fukuzawa K, Higashi K, Nazir KH, Wada E, Suyama A, Takegawa K, Goto M, Nakamura K, Furukawa K (2011) Enrichment and characterization of a trichloroethene-dechlorinating consortium containing multiple "dehalococcoides" strains. Biosci Biotechnol Biochem 75(7): 1268-74

81. Revetta RP, Matlib RS, Santo Domingo JW (2011) 16S rRNA gene sequence analysis of drinking water using RNA and DNA extracts as targets for clone library development. Curr Microbiol 63:50-59

82. Caporaso JG, Paszkiewicz K, Field D, Knight R, Gilbert JA (2011) The Western English Channel contains a persistent microbial seed bank. ISME J 6(6):1089-1093

83. O'dor RK, Fennel K, VandenBerghe E (2009) A one ocean model of biodiversity. Deep-Sea Res II 56:1816-1823

84. Humayoun SB, Bano N, Hollibaugh JT (2003) Depth distribution of microbial diversity in Mono Lake, a meromictic Soda Lake in California. Appl Environ Microbiol 69:1030-1042

85. Székely AJ, Berga M, Langenheder S (2013) Mechanisms determining the fate of dispersed bacterial communities in new environments. ISME J 7(1):61-71

86. Comeau AM, Harding T, Galand PE, Vincent WF, Lovejoy C (2012) Vertical distribution of microbial communities in a perennially stratified Arctic lake with saline, anoxic bottom waters. Sci Rep 2:604

87. Booth IR (1985) Regulation of cytoplasmic $\mathrm{pH}$ in bacteria. Microbiol Rev 49(4):359-378

88. Krause E, Wichels A, Gimenez L, Lunau M, Schilhabel MB, Gerdts $\mathrm{G}$ (2012) Small changes in $\mathrm{pH}$ have direct effects on marine bacterial community composition: a microcosm approach. PLoS ONE 7(10), e47035. doi:10.1371/journal.pone.0047035 